\title{
IDENTIFIKASI MOLEKULER BEAN COMMON MOSAIC VIRUS YANG BERASOSIASI DENGAN PENYAKIT MOSAIK KUNING KACANG PANJANG
}

\author{
Melinda $^{1}$, Tri Asmira Damayanti², \& Sri Hendrastuti Hidayat ${ }^{2}$ \\ ${ }^{1}$ Fakultas Pertanian, Universitas Negeri Papua, Manokwari \\ Jl. Gunung Salju, Amban Manokwari, Papua Barat \\ ${ }^{2}$ Departemen Proteksi Tanaman, Fakultas Pertanian, Institut Pertanian Bogor \\ Jl. Kamper, Kampus IPB Dramaga, Bogor 16680 \\ E-mail: triasmiradamayanti@gmail.com
}

\begin{abstract}
Molecular identification of bean common mosaic virus associated with yellow mosaic disease on yard long bean. Bean common mosaic virus (BCMV) has been reported as one of the causal agents of yellow mosaic disease on yard long bean in West Java and Central Java. Infected plants showed mosaic, yellowing, and mixture of yellow mosaic. The research was conducted to identify the diversity of BCMV associated with yellow mosaic disease based on coat protein (CP) gene sequences. Symptomatic leaf samples were collected from yard long bean growing areas in several districts in West Java (Bogor, Cirebon, Subang, and Indramayu), and several districts in Central Java (Tegal, Klaten, Solo, Yogjakarta, Sleman, and Magelang). Molecular detection using RT-PCR method was carried out by using specific primer to BCMV which will amplify the CP gene. DNA fragment, \pm 860 bp in size, was successfully amplified from 8 out of 13 leaf samples, i.e samples from three villages in Bogor District (Cangkurawok, Bubulak, Bojong), and five samples from District of Cirebon, Subang, Solo, Sleman, and Tegal. Sequence analysis of those DNA fragment showed that 4 isolates (Bogor-Cangkurawok, Subang, Solo and Sleman) had the highest homology to BCMV-BIC from Taiwan, whereas 2 isolates (Cirebon and Tegal) had the highest homology to BCMVNL1 from England. Further, phyllogenetic analysis revealed that those of 4 isolates were closely related to BCMV-BIC from Taiwan based on nucleotide as well as amino acid sequences; while those other 2 isolates were closely related to BCMV-NL1 from England based on nucleotide sequences but closely related to BCMV-BIC Y from China based on amino acid sequences. Phyllogenetic analysis showed that those of $6 \mathrm{BCMV}$ isolates separated in two different clusters; 4 isolates (BogorCangkurawok, Subang, Solo, and Sleman) in cluster 1 together with BCMV-B1C from Taiwan, while other 2 isolates (Cirebon and Tegal) in cluster 2 together with BCMV-NL1.
\end{abstract}

Key words: bean common mosaic virus, coat protein, diversity, yard long bean

\section{ABSTRAK}

Identifikasi molekuler bean common mosaic virus yang berasosiasi dengan penyakit mosaik kuning kacang panjang. Bean common mosaic virus (BCMV) telah dilaporkan sebagai salah satu penyebab penyakit mosaik kuning di pertanaman kacang panjang di Jawa Barat dan Jawa Tengah. Tanaman terinfeksi menunjukkan gejala mosaik, menguning, dan campuran mosaik kuning. Penelitian ini dilakukan untuk mengidentifikasi keragaman BCMV yang berasosiasi dengan penyakit mosaik kuning berdasarkan urutan gen protein selubung (CP). Sampel yang bergejala dikumpulkan dari pertanaman kacang panjang di beberapa kabupaten di Jawa Barat (Bogor, Cirebon, Subang, dan Indramayu), dan beberapa kabupaten di Jawa Tengah (Tegal, Klaten, Solo, Yogjakarta, Sleman, dan Magelang). Deteksi molekuler menggunakan metode RT-PCR, dilakukan dengan menggunakan primer spesifik BCMV yang menyandi gen CP. Fragmen DNA berukuran $\pm 860 \mathrm{pb}$ berhasil diamplifikasi 8 dari 13 sampel daun, yaitu sampel dari 3 desa di Kabupaten Bogor (Cangkurawok, Bubulak, Bojong) dan 5 sampel dari Kabupaten Cirebon, Subang, Solo, Sleman, dan Tegal. Analisis urutan fragmen DNA menunjukkan bahwa 4 isolat (Bogor-Cangkurawok, Subang, Solo dan Sleman) memiliki homologi tertinggi dengan BCMV-BlC dari Taiwan, sedangkan 2 isolat (Cirebon dan Tegal) memiliki homologi tertinggi dengan BCMV-NL1 dari Inggris. Analisis filogenetika lebih lanjut menunjukkan bahwa 4 isolat (Bogor-Cangkurawok, Subang, Solo, dan Sleman) memiliki kekerabatan yang dekat dengan BCMV-BlC dari Taiwan berdasarkan urutan nukleotida serta urutan asam amino, sedangkan 2 isolat (Cirebon dan Tegal), memiliki kekerabatan yang dekat dengan BCMV-NL1 dari Inggris berdasarkan urutan nukleotida dan memiliki kekerabatan yang dekat dengan BCMV-B1C Y dari Cina berdasarkan urutan asam amino. Analisis filogenetika menunjukkan 6 isolat BCMV terpisah menjadi 2 kluster; 4 isolat (BogorCangkurawok, Subang, Solo, dan Sleman) pada kluster 1 bersama BCMV-BIC dari Taiwan dan 2 isolat (Cirebon dan Tegal) pada kluster 2 bersama BCMV-NL1.

Kata kunci: bean common mosaic virus, kacang panjang, keragaman, protein selubung 


\section{PENDAHULUAN}

Tanaman kacang panjang (Vigna sinensis ssp. sesquipedalis) merupakan tanaman hortikultura yang memiliki peluang sebagai komoditas strategis untuk pangan masa depan serta sebagai alternatif sumber pertumbuhan ekonomi (Pitojo, 2006). Berdasarkan data Badan Pusat Statistik (2011), produksi kacang panjang di Indonesia pada tahun 2010 mencapai 489.449 ton dan pada tahun 2011 menurun menjadi 458.307 ton. Salah satu faktor pembatas produksi kacang panjang adalah gangguan hama dan penyakit tanaman. Hama yang umum ditemukan pada pertanaman kacang panjang adalah kutu daun Aphis craccivora Koch, penggerek polong (Maruca testulalis Geyer), kutu kebul (Bemisia tabaci Genn), ulat jengkal (Plusia chalcites Esper), lalat kacang (Agromyza phaseoli Cog), tungau merah (Tetranychus cinnabarinus Boisd.) dan kepik polong (Riptortus linearis F.). Sedangkan penyakit yang sering ditemui diantaranya adalah layu (Fusarium oxysporum f.sp. phaseoli), antraknosa (Colletotrichum lindemuthianum (Sacc et Magn), mosaik yang disebabkan oleh Bean common mosaic virus (BCMV), Bean yellow mosaic virus (BYMV) dan Cowpea aphid-borne mosaic virus (CABMV), daun kecil kacang panjang (Cowpea witches-broom virus) dan puru akar (Meloidogyne sp.) (Anwar et al., 2005; Haryanto et al., 2010; Lazuardi, 2005; Siregar, 1996).

Pada tahun 2008-2009, Damayanti et al. (2009) melaporkan insidensi penyakit mosaik kuning kacang panjang yang meluas di beberapa daerah pantai utara Jawa Barat. Tanaman yang terinfeksi menunjukkan gejala mosaik kuning, penghambatan pertumbuhan dan malformasi daun. Infeksi pada tanaman yang masih muda menyebabkan tidak terbentuknya polong dan jika infeksinya sangat parah dapat mengakibatkan kematian. Salah satu virus yang terdeteksi pada tanaman kacang panjang dengan gejala mosaik kuning dari daerah Bubulak, Dramaga Bogor dan Sidorejo, Karanganyar Pekalongan adalah BCMV strain Blackeye (BCMV$\mathrm{BlC})$.

BCMV umumnya menginfeksi tanaman kacangkacangan seperti pada spesies Phaseolus vulgaris, Vigna unguiculata, dan V. radiata. Tanaman yang terinfeksi menunjukkan gejala utama mosaik dan nekrosis, tulang daun berwarna hijau tua sedangkan daerah interveinal menjadi hijau muda. Adanya perubahan warna daun biasanya diikuti dengan malformasi daun berupa kerutan dan menggulung. Gejala pada tanaman umumnya muncul 7 sampai 10 hari setelah inokulasi. Tipe gejala yang ditimbulkan ditentukan oleh strain virus, suhu lingkungan pertanaman dan genotipe inang. Terdapat 10 strain BCMV yang telah diketahui yaitu Blackeye, US1, US5, NL2, NL3, NL4, NL5, NL6, NL7 dan NL8 (Morales, 1988). Sebelumnya dilaporkan infeksi BCMV dan BCMNV (Bean common mosaic necrosis virus) menyebabkan gejala yang mosaik yang berbeda dari gejala khas pada tanaman Phaseolus lunatus (lima bean) di Peru (Melgarejo et al., 2007). Selain itu beberapa isolat BCMV-BlC juga dilaporkan menginfeksi vanili di India (Bhadramurthy \& Bhat, 2009) dan menjadi masalah serius yang mengancam produksi kedelai di Cina (Zhou et al., 2014).

Mengingat sedikitnya informasi mengenai strain BCMV atau keragaman BCMV yang menginfeksi tanaman kacang panjang di Indonesia, maka perlu dilakukan identifikasi secara molekuler terhadap BCMV yang menyebabkan penyakit mosaik kuning pada tanaman kacang panjang. Insidensi penyakit mosaik kuning di lapangan dilaporkan masih cukup tinggi terutama di Jawa Barat dan Jawa Tengah. Oleh karena itu penelitian ini bertujuan untuk mengidentifikasi keragaman BCMV dari tanaman kacang panjang yang berasal dari beberapa daerah di Jawa Barat dan Jawa Tengah.

\section{METODE PENELITIAN}

Tempat dan Waktu. Penelitian dilaksanakan di Laboratorium Virologi Tumbuhan, Departemen Proteksi Tanaman, Fakultas Pertanian, Institut Pertanian Bogor mulai bulan Juni sampai dengan Desember 2012.

Pengamatan Gejala di Lapangan serta Pengambilan Sampel Tanaman. Pengamatan gejala dan pengambilan sampel dilakukan di pertanaman kacang panjang di daerah Dramaga, Kabupaten Bogor Propinsi Jawa Barat yaitu di daerah Cangkurawok, Bubulak, Situgede dan Bojong. Sebanyak 20 sampel daun yang menunjukkan gejala mosaik kuning diambil dari masing-masing lokasi. Sampel daun dengan gejala kuning juga diperoleh dari koleksi Laboratorium Virologi Tumbuhan IPB yaitu sampel yang berasal dari beberapa Kabupaten di Jawa Barat (Bogor, Cirebon, Subang, dan Indramayu) dan beberapa kabupaten di Jawa Tengah (Tegal, Solo, Yogjakarta, Sleman, Klaten, dan Magelang).

\section{Deteksi BCMV dengan Teknik Reverse Transcription-Polymerase Chain Reaction (RT- PCR)}

Ekstraksi RNA Total. RNA total diekstraksi dari jaringan daun tanaman bergejala sebanyak $0,1 \mathrm{~g}$ menggunakan NucleoSpin RNA Plant (MachereyNagel Inc., USA) atau Xprep Plant RNA Mini Kit 
(Philakorea Technology) dilakukan sesuai protokol yang dianjurkan pembuatnya.

Sintesis cDNA. RNA total hasil ekstraksi selanjutnya digunakan untuk proses transkripsi balik (reverse transcription-RT) menjadi cDNA (complementary DNA) dengan menggunakan enzim Reverse Transcriptase. Reaksi transkripsi balik terdiri dari: $4 \mu \mathrm{l}$ RNA total, $4 \mu 15 \mathrm{x}$ bufer RT, $2 \mu 1$ DTT (dithiothreitol) $50 \mathrm{mM}, 2 \mu \mathrm{dNTP} 10 \mathrm{mM}, 1 \mu \mathrm{M}-\mathrm{MuLV}$ (200 U/ $\mu \mathrm{l}), 1 \mu \mathrm{l}$ RNase inhibitor (40 U/ $\mu \mathrm{l}), 2 \mu \mathrm{l}$ oligo $\mathrm{d}(\mathrm{T})_{18} 10 \mu \mathrm{M}$ dan air bebas nuklease sampai volume total $20 \mu$ l. Reaksi RT dilakukan dalam mesin Automated Thermal Cycler (Gene Amp PCR System 9700; PE Applied Biosystem, USA) yang diprogram untuk satu siklus pada suhu $25^{\circ} \mathrm{C}$ selama 5 menit, $42^{\circ} \mathrm{C}$ selama 60 menit, dan $70^{\circ} \mathrm{C}$ selama 15 menit. Siapan cDNA hasil RT ini digunakan sebagai DNA cetakan dalam reaksi amplifikasi.

Amplifikasi DNA dengan PCR. Amplifikasi DNA virus dilakukan dengan metode Polymerase Chain Reaction (PCR) dengan menggunakan pasangan primer spesifik gen coat protein BCMV yaitu primer forward $\mathrm{BCMV}-\mathrm{F}$ dan primer reverse BCMV-R (Anggraini \& Hidayat, 2014) dengan hasil amplifikasi berukuran \pm 860 $\mathrm{pb}$ (pasang basa). Reaksi PCR terdiri dari: $1 \mu \mathrm{l}$ cDNA, 12,5 $\mu 1$ premix Go Taq Green (Promega Jepang), masing-masing $1 \mu \mathrm{l}$ primer BCMV-F dan BCMV-R (10 $\mu \mathrm{M} / \mu \mathrm{l})$, dan air bebas nuklease sampai volume total 25 $\mu 1$. Amplifikasi dilakukan pada Automated Thermal Cycler (Gene Amp PCR System 9700; PE Applied Biosystem, USA). Amplifikasi didahului dengan denaturasi awal pada suhu $94{ }^{\circ} \mathrm{C}$ selama 5 menit, dilanjutkan dengan 35 siklus yang terdiri dari denaturasi pada suhu $94{ }^{\circ} \mathrm{C}$ selama 1 menit, penempelan primer pada suhu $68^{\circ} \mathrm{C}$ selama 1 menit dan ekstensi pada suhu $72{ }^{\circ} \mathrm{C}$ selama 1 menit. Siklus terakhir ditambahkan 7 menit pada suhu $72^{\circ} \mathrm{C}$ untuk tahapan sintesis dan siklus berakhir pada suhu $4^{\circ} \mathrm{C}$.

Visualisasi DNA. Gel agarosa konsentrasi $1 \%$ dibuat dari $0,3 \mathrm{~g}$ agarosa yang dilarutkan dalam bufer TBE $0,5 \mathrm{x}$ sebanyak $30 \mathrm{ml}$ dengan bantuan microwave. Sebelum digunakan, larutan gel agarosa didinginkan hingga suhu $50{ }^{\circ} \mathrm{C}$ selama kurang lebih 15 menit lalu ditambahkan $3 \mu \mathrm{l}$ ethidium bromide $(0,5 \mu \mathrm{g} / 10 \mathrm{ml})$. Elektroforesis dilakukan pada tegangan $100 \mathrm{~V}$ selama 20 menit. Hasil elektroforesis selanjutnya divisualisasi dibawah transilluminator ultraviolet dan didokumentasi dengan kamera digital.
Perunutan dan penyejajaran DNA. Fragmen DNA hasil amplifikasi PCR dikirim ke First Base Genetica Science (Singapura) untuk proses perunutan nukleotida. Hasil perunutan nukleotida digunakan untuk melihat tingkat kesamaan dengan runutan nukleotida yang terdapat di GenBank menggunakan program BLAST (Basic Local Alignment Search Tool) (http:// www.ncbi.nlm.nih.gov/BLAST) dan identitas matriks homologi menggunakan perangkat lunak BioEdit (Hall, 1999), serta MEGA 5.05. untuk konstruksi pohon filogenetika.

\section{HASIL DAN PEMBAHASAN}

\section{Gejala Mosaik Kuning pada Tanaman Kacang} Panjang di Lapangan. Sampel-sampel tanaman kacang panjang sakit yang diambil dari lapangan menunjukkan gejala mosaik kuning. Gejala mosaik kuning di lapangan dapat dibedakan menjadi dua kelompok berdasarkan warna dan perubahan bentuk pada daun. Kelompok pertama menunjukkan gejala mosaik kuning dengan pola mosaik berwarna hijau muda sampai tua kekuningan dengan warna terang, terjadi penebalan tulang daun (vein banding), malformasi daun (daun menggulung seperti krupuk, mengerut sepanjang tulang daun), dan terdapat lepuhan. Bila gejala berlanjut tanaman menjadi kerdil dan terhambat pertumbuhannya. Kelompok kedua menunjukkan gejala dengan pola mosaik berwarna hijau muda sampai tua dengan batas kuning yang kurang tegas, terjadi penebalan tulang daun (vein banding), dan malformasi daun (Tabel 1).

Gejala yang ditunjukkan tanaman sampel pada kelompok pertama mengindikasikan tanaman terinfeksi Bean common mosaic virus (BCMV). Tanaman yang terinfeksi BCMV menunjukkan gejala utama mosaik dan nekrosis, tulang daun berwarna hijau tua sedangkan daerah interveinal menjadi hijau muda diikuti dengan perubahan warna daun dan malformasi daun berupa kerutan dan menggulung (CABI, 2007). Menurut Agrios (2005) gejala awal daun yang terinfeksi BCMV adalah daun menjadi bergelombang kemudian warna daun menjadi berubah dan tidak merata, seiring dengan berjalannya waktu daun melengkung ke bawah dan ke atas. Daun selanjutnya terlihat mengerut dan terjadi mosaik, malformasi daun dan penebalan di sekitar pertulangan daun berwarna hijau tua.

Berdasarkan deskripsi yang diuraikan di atas, ada indikasi bahwa gejala mosaik kuning pada kacang panjang dapat disebabkan oleh infeksi beberapa jenis virus. Kepastian adanya infeksi BCMV dapat ditentukan berdasarkan metode deteksi secara molekuler. 
Deteksi Virus dengan Metode RT-PCR dan Perunutan Basa Nukleotida. Pita DNA berukuran $\pm 860 \mathrm{pb}$ berhasil teramplifikasi dari sampel asal Kabupaten Bogor (Desa Cangkurawok, Bubulak, Bojong), Cirebon, Subang, Solo, Sleman, dan Tegal. BCMV tidak teramplifikasi dari sampel asal BogorSitugede, Indramayu, Yogjakarta, Klaten dan Magelang (Gambar 1). Hasil deteksi ini menunjukkan bahwa pengamatan gejala penyakit saja tidak cukup untuk mendeteksi dan mengidentifikasi virus pada tanaman sehingga diperlukan diagnosis secara molekuler. Damayanti et al. (2009) berhasil mendeteksi BCMV dan Cucumber mosaic virus (CMV) dari tanaman kacang panjang yang menunjukkan gejala mosaik kuning. Oleh karena itu gejala mosaik yang tampak pada sampel- sampel daun pada penelitian ini, kemungkinan juga disebabkan oleh infeksi virus selain BCMV. Nurulita (2014) melaporkan PCR DNA menggunakan primer universal Begomovirus dari gejala mosaik kuning kacang panjang positif Begomovirus.

Pita DNA hasil amplifikasi digunakan untuk perunutan basa nukleotida dan diperoleh hasil perunutan berkisar 779 sampai $861 \mathrm{pb}$ (Tabel 2). Setelah dilakukan analisis homologi terhadap sekuen yang ada di Genbank menggunakan program BLAST (http:// www.ncbi.nlm.nih.gov/BLAST) diketahui bahwa isolatisolat Bogor-Cangkurawok, Subang, Solo dan Sleman memiliki 99\% sampai 100\% homologi dengan BCMVBlC asal Taiwan (AY575773.1), sedangkan isolat-isolat Cirebon dan Tegal memiliki 90\% homologi dengan

Tabel 1. Tipe gejala dan hasil deteksi BCMV menggunakan metode RT-PCR

\begin{tabular}{llc}
\hline \multicolumn{1}{c}{ Asal sampel } & Tipe gejala $^{*}$ & Hasil PCR \\
\hline Bogor-Cangkurawok & Mkb, Md, Vb, K & + \\
-Bubulak & Mks, Vb & + \\
-Situgede & Mks, Vb & - \\
-Bojong & Mks, Vb & + \\
Cirebon & Mkb, Md, Vb & + \\
Subang & Mkb, Md, Vb, K & + \\
Indramayu & Mks, Vb & - \\
Klaten & Mks, Vb & - \\
Solo & Mkb, Md, Vb, K & + \\
Yogjakarta & Mks, Vb & - \\
Sleman & Mks, Md, Vb & + \\
Tegal & $M k b, M d, ~ V b$ & + \\
Magelang & Mkr, Vb & - \\
\hline
\end{tabular}

${ }^{*} \mathrm{Mkr}=$ Mosaik kuning ringan; $\mathrm{Mks}=$ Mosaik kuning sedang; $\mathrm{Mkb}=$ Mosaik kuning berat; $\mathrm{Md}=$ Malformasi daun; $\mathrm{Vb}=$ Vein banding; $\mathrm{K}=$ Kerdil + + = $\mathrm{BCMV} ;-$ = bukan $\mathrm{BCMV}$.

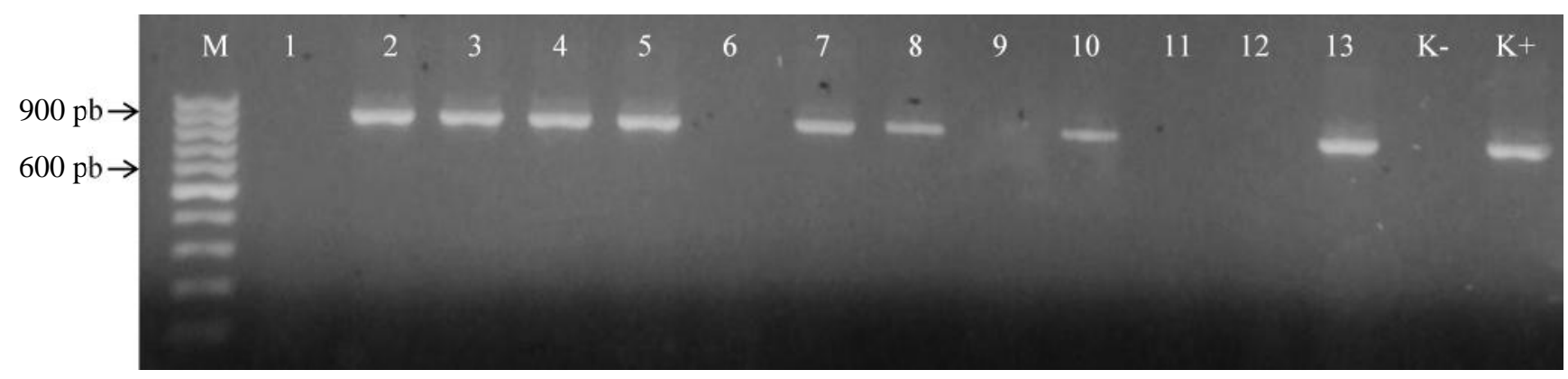

Gambar 1. Pita DNA hasil amplifikasi dengan primer spesifik gen CP BCMV (BCMV-F/BCMV-R) pada gel agarosa 1\%. M = Penanda DNA 100 pb, DNA sampel asal; 1. Situgede, 2. Cangkurawok, 3.Bubulak. Bojong, 5. Subang, 6. Indramayu, 7. Cirebon, 8. Tegal, 9. Klaten, 10. Solo, 11. Magelang, 12. Yogjakarta, 13. Sleman; K- = Kontrol negatif (air), K+ = Kontrol positif (isolat BCMV) 
BCMV-NL1 asal Inggris (AY112735) (Tabel 2). Hasil diagnosis sesuai dengan penelitian Damayanti et al. (2009) yang melaporkan bahwa salah satu virus yang terdeteksi pada tanaman kacang panjang dengan gejala mosaik kuning adalah BCMV strain Blackeye (BCMV$\mathrm{BlC})$.

Analisis Basa Nukleotida dan Asam Amino Gen Protein Selubung BCMV. Hasil perunutan basa nukleotida gen protein selubung BCMV diperoleh ukuran yang berbeda (Tabel 2) sehingga untuk analisis runutan basa nukleotida digunakan ukuran yang sama yaitu 777 nukleotida yang mengkode 259 asam amino. Analisis runutan basa nukleotida gen protein selubung tersebut menunjukkan tingkat homologi yang tinggi antara keenam isolat BCMV asal Jawa Barat dan Jawa Tengah, yaitu berkisar antara 89,1-100\%. Isolat Bogor-Cangkurawok, Subang, Solo, dan Sleman memiliki tingkat homologi yang sangat dekat satu dengan lainnya $(99,8-100 \%)$ tetapi tingkat homologinya lebih rendah dibandingkan dengan

Tabel 2. Hasil BLAST runutan nukleotida isolat BCMV dan persentase homologinya dengan isolat BCMV dari GenBank

\begin{tabular}{|c|c|c|c|c|c|}
\hline \multirow[b]{2}{*}{ Isolat } & \multirow{2}{*}{$\begin{array}{l}\text { Panjang } \\
\text { nukleotida } \\
(\mathrm{pb})\end{array}$} & \multicolumn{4}{|c|}{ Homologi } \\
\hline & & $\%$ & Strain BCMV & $\begin{array}{c}\text { Asal strain } \\
\text { (Tanaman/Negara) }\end{array}$ & No. aksesi \\
\hline Bogor-Crwk* & 861 & 100 & BCMV-BlC** & Kacang panjang/Taiwan & AY575773.1 \\
\hline Cirebon & 861 & 90 & BCMV-NL1 & Buncis/Inggris & AY112735 \\
\hline Subang & 861 & 100 & BCMV-BIC & Kacang panjang/Taiwan & AY575773.1 \\
\hline Solo & 779 & 99 & BCMV-BlC & Kacang panjang/Taiwan & AY575773.1 \\
\hline Sleman & 861 & 100 & BCMV-BIC & Kacang panjang/Taiwan & AY575773.1 \\
\hline Tegal & 861 & 90 & BCMV-NL1 & Buncis/Inggris & AY112735 \\
\hline
\end{tabular}

${ }^{*}$ Crwk $=$ Bogor-cangkurawok, $* *$ BCMV-BlC $=$ Bean common mosaic virus strain Blackeye Cowpea

Tabel 3. Homologi nukleotida dengan BCMV dari negara lain

\begin{tabular}{|c|c|c|c|c|c|c|c|c|c|c|c|c|c|c|}
\hline \multirow{2}{*}{ No } & \multicolumn{14}{|c|}{ Homologi $(\%)^{*}$} \\
\hline & 1 & 2 & 3 & 4 & 5 & 6 & 7 & 8 & 9 & 10 & 11 & 12 & 13 & 14 \\
\hline 1 & - & 99,8 & 99,8 & 89,3 & 89,1 & $\mathbf{9 9 , 8}$ & $\mathbf{9 9 , 8}$ & 99,3 & 90,8 & 96,3 & 92,0 & 89,5 & 59,3 & 69,1 \\
\hline 2 & & - & 100 & 89,3 & 89,3 & 100 & 100 & 99,4 & 90,9 & 96,5 & 92,1 & 89,7 & 59,3 & 69,1 \\
\hline 3 & & & - & 89,3 & 89,3 & 100 & 100 & 99.4 & 90,9 & 96,5 & 92,1 & 89,7 & 59,3 & 69,1 \\
\hline 4 & & & & - & 96,6 & 89,3 & 89,3 & 88,8 & 88,1 & 89,0 & 89,8 & 87,9 & 57,7 & 67,9 \\
\hline 5 & & & & & - & 89,3 & 89,3 & 88,8 & 88,4 & 89,1 & 90,0 & 88,8 & 57,9 & 68,0 \\
\hline 6 & & & & & & - & 100 & 99,4 & 90,9 & 96,5 & 92,1 & 89,7 & 59,3 & 69,1 \\
\hline 7 & & & & & & & - & 99,4 & 90,9 & 96,5 & 92,1 & 89,7 & 59,3 & 69,1 \\
\hline 8 & & & & & & & & - & 90,7 & 96,0 & 91,8 & 89,4 & 59,6 & 69,1 \\
\hline 9 & & & & & & & & & - & 90,2 & 96,1 & 88,2 & 57,5 & 68,7 \\
\hline 10 & & & & & & & & & & - & 91,3 & 89,1 & 58,7 & 67,8 \\
\hline 11 & & & & & & & & & & & - & 90,2 & 59 & 68,7 \\
\hline 12 & & & & & & & & & & & & - & 58,8 & 69,3 \\
\hline 13 & & & & & & & & & & & & & - & 58,8 \\
\hline 14 & & & & & & & & & & & & & & - \\
\hline
\end{tabular}

${ }^{*}$ Tingkat homologi nukleotida dihitung menggunakan program Bioedit versi 7.0.0. Angka dengan cetak tebal hitam menunjukkan homologi antar sesama isolat asal Jawa Barat dan Jawa Tengah dengan isolat dari Genbank. 1) BCMV Solo; 2) BCMV Bogor-Cangkurawok; 3) BCMV Subang; 4) BCMV Cirebon; 5) BCMV Tegal; 6) BCMV Sleman; 7) BCMV-BIC-TAIWAN (AY575773.1); 8) BCMV-B1C-PSU1 (FR775796.1); 9) BCMV-B1C-NY15 (S66252.1); 10) BCMV-BIC-Y (AJ312438.1); 11) BCMV-NL1 (AY112735); 12) BCMV-PSt-T13 (HM776126.1); 13) BYMV-HP (KC011006); dan 14) CabMV-DF-Brs (DQ397532.1). 
isolat Cirebon dan Tegal (89,1-89,3\%). Dua isolat BCMV asal Cirebon dan Tegal memiliki tingkat homologi yang sangat dekat satu dengan lainnya $(96,6 \%)$ tetapi tidak terlalu dekat dengan keempat isolat lainnya (Tabel 3).

Analisis homologi dengan melibatkan beberapa isolat lain dari Genbank menunjukkan bahwa 4 isolat BCMV (isolat-isolat Bogor-Cangkurawok, Subang, Solo dan Sleman) memiliki hubungan homologi yang dekat dengan BCMV-B1C dari Taiwan (AY575773.1) dan BCMV-BlC PSU1 dari Thailand (FR775796.1) dengan tingkat homologi berkisar 99,3-100\%. Dua isolat BCMV asal Cirebon dan Tegal lebih dekat hubungan kekerabatannya dengan BCMV-NL1 (AY112735) dari Inggris dengan tingkat homologi 89,8-90,0\% dibandingkan hubungannya dengan BCMV-BlC asal Taiwan ataupun BCMV-BIC PSU1 asal Thailand. Perbedaan tingkat homologi tersebut memberikan indikasi adanya keragaman diantara isolat-isolat BCMV dari daerah Jawa Barat dan Jawa Tengah.

Analisis runutan asam amino gen protein selubung menunjukkan tingkat homologi yang tinggi antara keenam isolat BCMV asal Jawa Barat dan Jawa Tengah, yaitu berkisar antara 93,0-100\%. Isolat Bogor-Cangkurawok,
Subang, Solo, dan Sleman memiliki tingkat homologi yang sangat dekat satu dengan lainnya $(99,6-100 \%)$ tetapi tingkat homologinya tidak terlalu dekat dengan isolat Cirebon dan Tegal (93,0-93,4\%). Dua isolat BCMV asal Cirebon dan Tegal memiliki tingkat kekerabatan yang sangat dekat satu dengan lainnya $(98,8 \%)$ tetapi tidak terlalu dekat dengan keempat isolat lainnya (Tabel $4)$.

Analisis kekerabatan dengan melibatkan beberapa isolat lain dari Genbank menunjukkan bahwa 4 isolat BCMV dari Bogor-Cangkurawok, Subang, Solo dan Sleman memiliki hubungan kekerabatan yang dekat dengan BCMV-BlC dari Taiwan (AY575773.1) dengan tingkat kesamaan berkisar 99,6-100\%. Dua isolat BCMV asal Cirebon dan Tegal lebih dekat hubungan kekerabatannya dengan BCMV-BlC Y asal Cina (AJ312438.1) dengan tingkat kesamaan 93,8\% dibandingkan hubungannya dengan BCMV-BlC asal Taiwan.

Menurut Adams et al. (2005), sekuen demarkasi gen protein selubung dalam Potyvirus disebut spesies yang sama jika homologi nukleotidanya berkisar $76-77 \%$ dan homologi runutan asam aminonya $82 \%$. Homologi nukleotida dan asam amino 6 isolat BCMV yang diisolasi

Tabel 4. Homologi asam amino dengan BCMV asal negara lain

\begin{tabular}{|c|c|c|c|c|c|c|c|c|c|c|c|c|c|c|}
\hline \multirow{2}{*}{ N0. } & \multicolumn{14}{|c|}{ Homologi $(\%)$} \\
\hline & 1 & 2 & 3 & 4 & 5 & 6 & 7 & 8 & 9 & 10 & 11 & 12 & 13 & 14 \\
\hline 1 & - & 99,6 & 99,6 & 93,0 & 93,0 & 99,6 & 99,6 & 99,2 & 92,2 & 99,2 & 93,0 & 92,2 & 57,3 & 66,4 \\
\hline 2 & & - & 100 & 93,4 & 93,4 & 100 & 100 & 99,6 & 92,6 & 99,6 & 93,4 & 92,6 & 57,3 & 66,4 \\
\hline 3 & & & - & 93,4 & 93,4 & 100 & 100 & 99,6 & 92,6 & 99,6 & 93,4 & 92,6 & 57,3 & 66,4 \\
\hline 4 & & & & - & 98,8 & 93,4 & 93,4 & 93,0 & 90,7 & 93,8 & 91,8 & 93,0 & 57,3 & 67,5 \\
\hline 5 & & & & & - & 93,4 & 93,4 & 93,0 & 91,1 & 93,8 & 92,2 & 93,0 & 57,3 & 67,5 \\
\hline 6 & & & & & & - & 100 & 99,6 & 92,6 & 99,6 & 93,4 & 92,6 & 57,3 & 66,4 \\
\hline 7 & & & & & & & - & 99,6 & 92,6 & 99,6 & 93,4 & 92,6 & 57,3 & 66,4 \\
\hline 8 & & & & & & & & - & 93,0 & 992 & 93,8 & 93,0 & 57,3 & 66,7 \\
\hline 9 & & & & & & & & & - & 93,0 & 94,9 & 90,7 & 57,3 & 66,7 \\
\hline 10 & & & & & & & & & & - & 93,8 & 93,0 & 57,3 & 66,4 \\
\hline 11 & & & & & & & & & & & - & 92,6 & 58,4 & 66,7 \\
\hline 12 & & & & & & & & & & & & - & 58 & 68,3 \\
\hline 13 & & & & & & & & & & & & & - & 54,9 \\
\hline 14 & & & & & & & & & & & & & & - \\
\hline
\end{tabular}

*Tingkat homologi nukleotida dihitung menggunakan program BioEdit versi 7.0.0. Angka dengan cetak tebal hitam menunjukkan homologi antar sesama isolat asal Jawa Barat dan Jawa Tengah dengan isolat dari Genbank. 1) BCMV Solo; 2) BCMV Cangkurawok; 3) BCMV Subang; 4) BCMV Cirebon; 5) BCMV Tegal; 6) BCMV Sleman; 7) BCMV-BlC-TAIWAN (AY575773.1); 8) BCMV-BlC-PSU1 (FR775796.1); 9) BCMV-BIC-NY15 (S66252.1); 10) BCMV-BlC-Y (AJ312438.1); 11) BCMV-NL1 (AY112735); 12) BCMV-PSt-T13 (HM776126.1); 13) BYMV-HP (KC011006); dan 14) CabMV-DF-Brs (DQ397532.1). 
dari kacang panjang dengan isolat-isolat BCMV di Genbank berturut-turut berkisar 89,3-100\% dan 93,0$100 \%$. Hal ini menunjukkan keenam isolat tersebut terbukti merupakan BCMV.
Filogenetika Berdasarkan Runutan Basa Nukleotida dan Asam Amino Gen Protein Selubung BCMV. Analisis filogenetika berdasarkan runutan basa nukleotida gen protein selubung BCMV 6

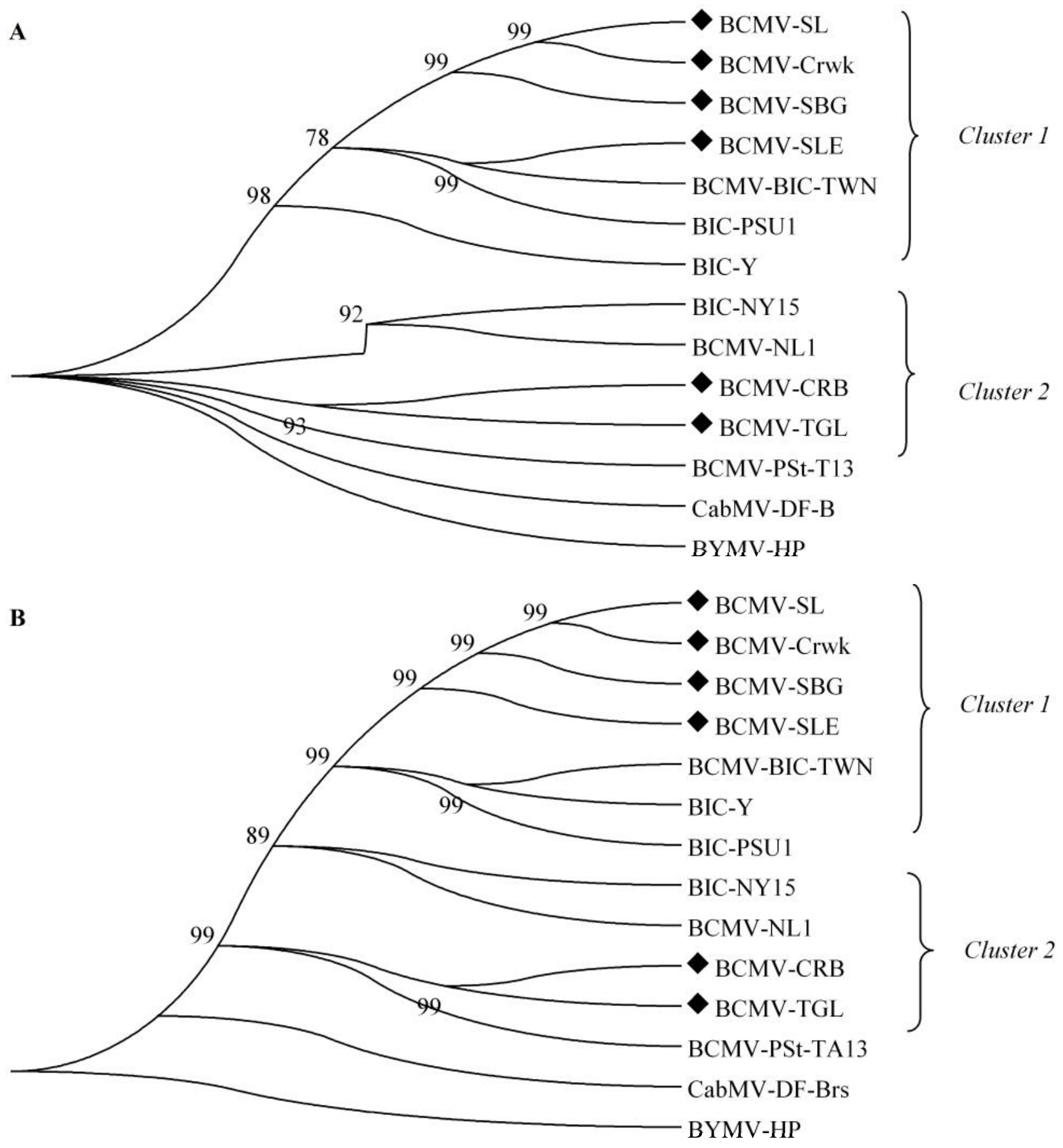

Gambar 2. Pohon filogenetika berdasarkan sekuen nukleotida (A) dan sekuen asam amino (B) BCMV. BYMVHP dan CABMV-DF-Brs digunakan sebagai out group. Isolat BCMV: BGR-Crwk. BogorCangkurawok, CRB. Cirebon, SBG. Subang, TGL. Tegal, SLE. Sleman, SL. Solo. Pohon filogenetika dibuat dengan Software MEGA v5.05 menggunakan 1000 kali bootstrap 
isolat asal Jawa Barat dan Jawa Tengah terhadap isolat dari negara lain menunjukkan terbentuknya 2 kelompok/ cluster. Keenam isolat tersebut terbagi kedalam cluster yang berbeda. Cluster pertama terdiri dari isolat-isolat Bogor-Cangkurawok, Subang, Solo dan Sleman, berada dalam satu cluster yang dekat dengan isolat BCMVBIC Taiwan, BCMV-B1C Y dan BCMV-BIC PSU1. Cluster kedua terdiri dari isolat-isolat Cirebon dan Tegal, berada dalam satu cluster yang dekat dengan isolat BCMV-BlC NY15, BCMV-NL1 dan BCMV-PSt-TA13 (Gambar 2a). Hal ini menunjukkan adanya keragaman isolat BCMV ditemukan diantara enam isolat. Sebagai pembanding di luar cluster (outgroup) digunakan Bean yellow mosaic virus-HP (BYMV-HP) dan Cowpea aphid-borne mosaic virus-DF-Brs (CabMV-DF-Brs).

Analisis filogenetika berdasarkan sekuen asam amino menunjukkan terbentuknya 2 cluster yang sama dengan runutan basa nukleotida. Walaupun membentuk 2 cluster, namun kekerabatan antar isolat masih sangat dekat dengan isolat BCMV-BlC dari Taiwan dan BCMV-BlC Y dari Cina (Gambar 2b). Isolat BCMV$\mathrm{BlC}$ asal Taiwan dan BCMV-BlC asal Cina sebelumnya dilaporkan menyebabkan penyakit yang parah dengan gejala daun kuning pada kacang panjang di Taiwan dan Cina (Zheng et al., 2002; Wang \& Fang, 2004).

\section{SIMPULAN}

Gejala mosaik kuning pada tanaman kacang panjang di lapangan sangat bervariasi. Deteksi molekuler menggunakan primer spesifik CP-BCMV berhasil mengamplifikasi pita DNA dari sampel tanaman asal Jawa Barat (Bogor; Cangkurawok, Bubulak, Bojong), Subang, dan Cirebon dan asal Jawa Tengah (Solo, Sleman, dan Tegal). Gejala mosaik kuning pada tanaman kacang panjang tidak hanya terinfeksi oleh BCMV tetapi kemungkinan disebabkan oleh infeksi virus lain. Isolat BCMV asal Bogor-Cangkurawok, Subang, Solo dan Sleman memiliki homologi dan kekerabatan yang dekat dengan BCMV-BlC dari Taiwan berdasarkan runutan basa nukleotida dan asam amino. Isolat BCMV asal Cirebon dan Tegal memiliki homologi dan kekerabatan yang dekat dengan BCMV-NL1 dari Inggris berdasarkan runutan basa nukleotida, namun berdasarkan runutan asam amino lebih dekat ke BCMVBlC Y dari Cina.

\section{SANWACANA}

Penelitian terlaksana atas dana pendidikan dan penelitian dari NUFFIC AGRI-4 UNIPA untuk penulis utama dan secara parsial dari dana penelitian IPVDN tahun 2012

\section{DAFTAR PUSTAKA}

Adams MJ, Antoniw JF, \& Fauquet CM. 2005. Molecular criteria for genus and species discrimination within the family Potyviridae. Arch Virol. 150(3): 459-479.

Agrios GN. 2005. Plant Pathology. $5^{\text {th }}$ eds. Academic Press. New York.

Anggraini S \& Hidayat SH. 2014. Sensitivitas metode serologi dan polymerase chain reaction untuk mendeteksi Bean Common Mosaic Potyvirus pada kacang panjang. J. Fitopatol. Indones. 10(1): 17-22.

Anwar A, Sudarsono, \& Ilyas S. 2005. Perbenihan sayuran di Indonesia: kondisi terkini dan prospek bisnis benih sayuran. Bul Agron. 33(1): 38-47.

Badan Pusat Statistik. 2011. Produksi Sayuran di Indonesia. [internet]. Jakarta (ID). http:// www.bps.go.id/tab_sub/view.php. Diakses 19 November 2012.

Bhadramurthy V \& Bhat AI. 2009. Biological and molecular characterization of Bean common mosaic virus associated with vanilla in India. Indian J. Virol. 20(2): 70-77.

[CABI] Centre for Agriculture and Biosciences International. 2007. Crop Protection Compendium. (Serial Online). CAB International. Wallingford.

Damayanti TA, Alabi OJ, Naidu RA, \& Rauf A. 2009. Severe outbreak of a yellow mosaic disease on the yard long bean in Bogor, West Java. Hayati J. Biosci. 16(2): 78-82.

Haryanto E, Suhartini T, \& Rahayu E. 2010. Budi Daya Kacang Panjang. Penebar Swadaya, Jakarta. 
Hall TA. 1999. Bioedit: a user-friendly biological sequence alignment editor and analysis program for Windows 95/98/NT. Nucl. Acids Symp. Ser. 41:95-98.

Lazuardi F. 2005. Perkembangan beberapa penyakit penting pada kacang panjang (Vigna sinensis L.) di lahan petani sekitar kampus IPB Dramaga, Kabupaten Bogor. Skripsi. Institut Pertanian Bogor, Bogor.

Melgarejo TA, Lehtonen MT, Fribourg CE, Rannali M, \& Valkonen JPT. 2007. Strains of BCMV and BCMNV characterized from lima bean plants affected by deforming mosaic disease in Peru. Arch. Virol. 152(10): 1941-1949.

Morales FJ. 1988. Bean common mosaic virus. www.dpvweb.net/dpv/showdpv.php?dpvno=337. Diakses 12 Oktober 2012.

Nurulita S. 2014. Molecular characterization of Begomovirus infecting yard long bean (Vigna unguiculata subsp. sesquipedalis L.) and construction of its specific primers. Tesis. Institut Pertanian Bogor, Bogor.
Pitojo S. 2006. Benih Kacang Panjang. Kanisius, Yogyakarta.

Siregar S. 1996. Pengamatan hama dan penyakit penting tanaman kacang panjang (Vigna sinensis L.) di Kecamatan Ciampea, Kabupaten Bogor Jawa Barat. Skripsi. Institut Pertanian Bogor, Bogor.

Wang HL \& Fang CC. 2004. Molecular sequencing and analysis of the viral genomic regions of Blackeye cowpea mosaic virus Taiwan strain. Plant Pathol. Bull. 13: 117-126.

Zheng H, Chen J, Chen J, Adams MJ, \& Hou M. 2002. Bean common mosaic virus isolates causing different symptoms in asparagus bean in China differ greatly in the 5'-parts of their genomes. Arch. Virol. 147(6): 1257-1262.

Zhou GC, Wu XY, Zhang YM, Wu P, Wu XZ, Liu LW, Wang Q, Hang YY, Yang JY, Shao ZQ, Wang B, \& Chen JQ. 2014. A genomic survey of thirty soybean-infecting Bean common mosaic virus (BCMV) isolates from China pointed BCMV as a potential threat to soybean production. Virus Res. 191: 125-133. 